\title{
IMPROVING THE FIRM INNOVATION CAPACITY THROUGH THE ADOPTION OF STANDARDIZED INNOVATION MANAGEMENT SYSTEMS: A COMPARATIVE ANALYSIS OF THE ISO 56002:2019 WITH THE LITERATURE ON FIRM INNOVATION CAPACITY
}

\author{
O APRIMORAMENTO DA CAPACIDADE DE INOVAÇÃO PELA ADOÇÃO DE SISTEMAS DE \\ GESTÃO DE INOVAÇ̃̃O PADRONIZADOS: UMA ANÁLISE COMPARATIVA DA ISO \\ 56002:2019 COM A LITERATURA SOBRE CAPACIDADE DE INOVAÇÃO
}

\author{
MEJORA DE LA CAPACIDAD DE INNOVACIÓN MEDIANTE LA ADOPCIÓN DE SISTEMAS \\ ESTANDARIZADOS DE GESTIÓN DE LA INNOVACIÓN: UN ANÁLISIS COMPARATIVO DE \\ LA ISO 56002:2019 CON LA LITERATURA SOBRE CAPACIDAD DE INNOVACIÓN
}

Silvio Bitencourt da Silva ${ }^{1}$

Cite as - American Psychological Association (APA)

Silva, S. B. (2021, May/Aug.). Improving the firm innovation capacity through the adoption of standardized innovation management systems: a comparative analysis of the ISO 56002:2019 with the literature on firm innovation capacity. International Journal of Innovation - IJI, São Paulo, 9(2), 389-413.

https://doi.org/10.5585/iji.v9i2.19273.

\begin{abstract}
Objective of the study: Investigate how firm innovation capacity can be improved by adopting ISO 56002: 2019.

Methodology/approach: The methodology adopted is a comparative analysis of the ISO 56002: 2019 with the literature on firm innovation capacity. The methods employed in the study included a review of the literature on the dynamic capabilities and firm innovation capacity, and qualitative documentary research that consisted of three phases: pre-analysis, organization of documents, and the analysis of results, using information from the texts of the guidelines and processes indicated by ISO 56002: 2019, which additionally involved the ISO 56000 family of standards.

Originality/Relevance: The adoption of innovation management standards generates several theoretical challenges when exploring details of their implementation systematically and routinely and empirical challenges such as understanding the advent of ISO 56002: 2019 for innovation management.

Main results: Similarities were found between the determinants of innovation capacity and the ISO 56002: 2019 Clauses, as each of the seven factors found a relationship with one or more ISO 56002: 2019 clauses.

Theoretical/methodological contributions: The findings obtained can be used by researchers interested in studying different innovation management models, innovation capacity, and, particularly, the dynamics of continuous improvement of the performance of an innovation management system and its interrelationship and interaction with other factors.

Social/management contributions: Contrary to common sense in which the normalization of innovation management seems to be counter-intuitive, it is suggested that the adoption of ISO 56002:
\end{abstract}

\footnotetext{
1 Doutor em Administração de Empresas. Universidade do Vale do Rio dos Sinos - UNISINOS. São Leopoldo - RS, Brasil. sibitencourt@unisinos.br
} 
2019 allows the innovation process to be managed, systematized, and replicated improving firm innovation capacity.

Keywords: Dynamic capabilities. Firm innovation capacity. Innovation management. Continuous improvement. Standardization.

\section{Resumo}

Objetivo do estudo: Investigar como a capacidade de inovação pode ser aprimorada pela adoção da Norma ISO 56002:2019.

Metodologia/abordagem: A metodologia adotada é uma análise comparativa da ISO 56002: 2019 com a literatura sobre capacidade de inovação. O métodos empregados no estudo contemplaram uma revisão da literatura sobre capacidades dinâmicas e capacidade de inovação da empresa, e a pesquisa documental qualitativa que consistiu basicamente em três fases: a pré-análise, a organização dos documentos e a análise dos resultados, utilizando as informações oriundas dos textos das diretrizes e processos indicados pela Norma ISO 56002:2019 que, adicionalmente envolveu a família de normas ISO 56000.

Originalidade/relevância: A adoção de normas de gestão de inovação gera diversos desafios teóricos ao explorar detalhes de sua implementação de maneira sistêmica e rotineira e desafios empíricos como a compreensão do advento da Norma ISO 56002:2019 para gestão de inovação.

Principais resultados: Foram percebidas semelhanças entre os fatores determinantes da capacidade de inovação e as Cláusulas da Norma ISO 56002:2019, pois cada um dos sete fatores encontrou relação com uma ou mais cláusulas da Norma ISO 56002:2019. No entanto, os fatores investigados não abrangem a Cláusula 10, subitem 10.3, da ISO 56002:2019 que trata sobre melhoria contínua, sugerindo a oportunidade de introdução de um novo fator a estrutura utilizada para a investigação voltado para melhoria contínua da aptidão, adequação, eficácia e eficiência do sistema de gestão da inovação.

Contribuições teóricas/metodológicas: Os achados obtidos podem ser usados por pesquisadores interessados em estudar diferentes modelos de gestão de inovação, capacidade de inovação e, particularmente a dinâmica de melhoria contínua do desempenho de um sistema de gestão da inovação e sua inter-relação e interação com outros fatores.

Contribuições sociais/gerenciais: Ao contrário do senso comum em que a normalização da gestão da inovação parece ser contra intuitiva, sugere-se que a adoção da Norma ISO 56002:2019 permite que o processo de inovação possa ser gerenciado, sistematizado e replicado nas empresas aprimorando sua capacidade de inovação.

Palavras-chave: Capacidades dinâmicas. Capacidade de inovação. Gestão da inovação. Melhoria contínua. Normalização.

\section{Resumen}

Objetivo del estudio: Investigar cómo se puede mejorar la capacidad de innovación mediante la adopción de ISO 56002: 2019.

Metodología/enfoque: La metodología adoptada es un análisis comparativo de la ISO 56002: 2019 con la literatura sobre capacidad de innovación. Los métodos empleados en el estudio incluyeron una revisión de la literatura sobre las capacidades dinámicas y la capacidad de innovación de la empresa, y la investigación documental cualitativa que consistió básicamente en tres fases: preanálisis, organización de los documentos y el análisis de los resultados, utilizando la información de los textos de los lineamientos y procesos indicados por la Norma ISO 56002: 2019, que además involucró a la familia de normas ISO 56000.

Originalidad/relevancia: La adopción de estándares de gestión de la innovación genera varios desafíos teóricos al explorar los detalles de su implementación de manera sistemática y rutinaria y desafíos empíricos como comprender la llegada de ISO 56002: 2019 para la gestión de la innovación.

Principales resultados: Se encontraron similitudes entre los determinantes de la capacidad de innovación y las Cláusulas ISO 56002: 2019, ya que cada uno de los siete factores encontró una relación con una o más cláusulas ISO 56002: 2019. Sin embargo, los factores investigados no incluyen la cláusula 10, subpunto 10.3, de la norma ISO 56002: 2019 que trata sobre la mejora continua, lo que sugiere la 
oportunidad de introducir un nuevo factor a la estructura utilizada para la investigación dirigida a la mejora continua de la aptitud, adecuación, eficacia. y eficiencia del sistema de gestión de la innovación. Aportes teórico-metodológicos: Los hallazgos obtenidos pueden ser utilizados por investigadores interesados en estudiar diferentes modelos de gestión de la innovación, capacidad de innovación y, en particular, la dinámica de mejora continua del desempeño de un sistema de gestión de la innovación y su interrelación e interacción con otros factores.

Aportes sociales/gerenciales: Contrario al sentido común en el que la normalización de la gestión de la innovación parece contraria a la intuición, se sugiere que la adopción de ISO 56002: 2019 permite que el proceso de innovación sea gestionado, sistematizado y replicado en las empresas mejorando su capacidad de innovación.

Palabras clave: Capacidades dinámicas. Capacidad de innovación de las empresas. Gestión de la innovación. Mejora continua. Estandarización.

\section{Introduction}

Innovation management can be expressed in a management system in which an organization consciously implements practices that lead to better innovation results and, as such, be standardized, as argued by Tidd, Bessant \& Pavitt (1997: 26) "there is something in common around things that are successfully managed", however, managing innovation is neither easy nor automatic, as it requires skills and knowledge, which are significantly different from adopting a toolkit standard management and experience (Tidd \& Bessant, 2021).

According to a recent study on "best practices" for innovation management in large companies in Sweden (Celukanovs \& Wattle BJörk, 2019), the reason for dissatisfaction may lie not only in the tools themselves but in the skills, approaches, directions, organizational structures, measurements, top management commitment, and processes. Karlsson and Magnusson (2019) argue that a systematic approach to innovation, a concept developed by Terwiesch and Ulrich (2009) could, among other things, guide the organization in a better way to identify gaps in its innovation capacity by estimating and evaluating the results of innovation.

This systematic approach has been expressed at different levels, through the standardization of activity fields related to innovation, such as standards related to the manufacture of a product, management, delivery of a service or supply of materials including those of innovation management (Egyedi \& Ortt, 2017; Garechana, Río-Belver, Bildosola \& Salvador , 2017; Mavroeidis \& Tarnawska, 2017).

Previous studies on the Standardized Innovation Management Systems (SIMSs) suggest that the adoption of these types of standards positively influence the innovative potential of a company, through tools, techniques, and approaches that promote all types of innovations, improve organizational capacities, contribute to reaching of innovation and corporate results, enabling sustainable competitive advantages to be obtained in different contexts, industries and 
company sizes (Mir \& Casadesús, 2011; Mir \& Petnji, 2016; Caetano, 2017; Martínez-Costa, Jimenez-Jimenez \& del Pilar Castro-del-Rosario, 2019; Harrington, 2019; Merrill, 2019; Tidd, 2021).

One of the organizational capacities that could be improved through the adoption of SIMSs refers to the firm innovation capacity built from the literature on dynamic capabilities, a consequence or extension of the resource-based view, which deals with a theoretical structure that highlights the actions that managers can take that most affect innovation results (Lawson \& Samson, 2001; Breznik \& Hisrich, 2014; Alves, Barbieux, Reichert, Tello-Gamarra \& Zawislak, 2017; Silva \& Pedron, 2019; Djoumessi, Chen \& Cahoon, 2019).

The standardization of innovation management generates several theoretical and empirical challenges for management research that can benefit the field coherently and cumulatively by exploring details of its adoption systemically and routinely (Albors-Garrigos, Igartua, \& Peiro, 2018; Tidd \& Bessant, 2018; Tidd, 2021), among them its relationship with the firm innovation capacity and, specifically, the understanding of the advent of the new family of ISO 56000 standards under development since 2013 by ISO / TC 279 (ISO, 2013), focused on innovation management at the International Organization for Standardization - ISO, an international standard-setting body composed of representatives from various national standardization organizations that is providing a common language and framework for building an innovation capability (Hyland \& Karlsson, 2021). Similar to the quality management system that ISO established decades ago, this standard provides instructions related to best practices on how to manage innovation activities, projects, and programs (Benraouane \& Harrington, 2021).

Particularly, Mir and Casadesús (2011) and Mir and Petnji (2016) focus on the UNE 166002: 2014 Standard, which is one of the first Standardized Innovation Management Systems (SIMSs) with national certification that exists globally to reach a level of acceptance sufficient to enable an empirical study, point out that the debate over whether standardization of innovation is harmful or beneficial to innovative capacity will continue. However, it will only be resolved when empirical studies have demonstrated whether, in the various companies in which these types of standards have been implemented, improvements in their innovation capacity have been (or have not) been made (Mir \& Casadesús, 2011; Mir \& Petnji, 2016). However, as with the UNE 166002: 2014 Standard in its early stages, although the structure of ISO 56002:2019 is still in its early stages, and a few years of implementation are needed before sufficient data can be collected, some conceptual conclusions can also be drawn from a 
comparative analysis of the standard with the literature (Mir \& Casadesús, 2011; Mir \& Petnji, 2016).

Such challenges, value studies allow answering the following research question: how can the adoption of the ISO 56002: 2019 standard improve the firm innovation capacity? It leads to the central objective of this work, which is to investigate the improvement of firm innovation capacity through the adoption of ISO 56002: 2019 from a comparative analysis of the standard with the literature as noted by Mir and Casadesús (2011) and Mir and Petnji (2016).

As for the structure, in addition to this introductory section, this work presents, next, an approach on the resource-based view and dynamic capabilities, the scientific theoretical basis adopted in this study, and on the firm innovation capacity and its determining factors. Following, the methodological procedures adopted in the research are specified. Soon after, the family of ISO 56000 standards, with an emphasis on detailing the ISO 56002: 2019 standard. Afterward, discussions are conducted. Then, in the final considerations, the theoretical, managerial implications, and limitations of this study are detailed, in addition to recommendations for future research, and finally, the references used to carry out the research.

\section{Theoretical reference}

\subsection{Dynamic capabilities}

The resource-based view (RBV) is primarily concerned with the source and nature of an organization's strategic resources and capabilities (Priem \& Butler, 2001). Specifically, RBV advocates the optimized use of resources to achieve superior performance through sustainable competitive advantage (Barney, 1991; Barney \& Arikan, 2001; Barney, Wright \& Ketchen, 2001; Barney, 2001). According to its beginnings, these resources must be valuable, rare, inimitable, and non-replaceable (VRIN) to provide real advantages (Wernerfelt, 1984). Its conceptual foundations lead to the works of Schumpeter (1934), Penrose (1959), and Andrews (1971).

Still considered one of the most debated and successful theories in management studies (Nason \& Wiklund, 2018), RBV dominates the field of strategy and was expanded from its initial studies and addresses various types of resources, such as assets, capabilities, knowledge, skills, and processes, which, being unique, can lead to a strategic position considering the company's competitiveness (Barney, 2001). Also, several relevant theories and perspectives have evolved from RBV, such as dynamic capabilities (Teece, Pisano \& Shuen, 1997), relational view (Dyer \& Singh, 1998), knowledge-based view (Kogut \& Zander, 1992), and 
dependence on resources (Casciaro \& Piskorsky, 2005). From the above, and in particular, the concept of dynamic capabilities (DCs) can be seen as a consequence or as an extension of RBV from “[...] an enormous effort to understand, define, predict and measure how organizational capabilities shape the competitive advantage "(Pisano, 2017, p. 747) based on economic principles to understand how companies are created, organized and grow; how they innovate and compete; and how managers manage (Teece, 2019).

From a theoretical perspective, DCs have been one of the most significant and challenging issues in the field of strategy and may be seen as the "Holy Grail" of strategic management (Helfat et al., 2009). In a seminal article, Teece et al. (1997, p. 516) defined DCs as "the ability to integrate, create and reconfigure internal and external competencies to deal with rapidly changing environments".

Far from being consensual, the definition by Teece et al. (1997, p. 516) has been improved, questioned, and even reformulated in different ways. Zollo and Winter (2002, p. 340) explained the DCs as "learned and stable patterns of collective activities, through which the company systematically generates and modifies its operational routines in search of greater efficiency". In his definition, Winter (2003, p. 991) explained the DCs as the extension, modification, and creation of common resources and, for a capacity to be considered dynamic, the organization must be able to use it repeatedly and reliably. Still, Zahra, Sapienza \& Davidsson (2006, p. 918) defined DCs as "skills to reconfigure a company's resources and routines properly by its main decision-makers". Meanwhile, Wang and Ahmed (2007, p. 35) offered a more detailed definition of DCs as "a company's behavioral orientation to integrate, reconfigure, renew and continually recreate its resources and capabilities". Otherwise, Schriber \& Löwstedt, (2020), explain DCs as “[...] how to respond to dynamic environments by reconfiguring inert and insufficiently flexible ordinary capacities".

The association of DCs with innovation capacity is not new, for example, Breznik and Hisric (2014) identified common aspects between DCs and innovation capacity (central role of learning, strategic orientation, main characteristics, role of management, and nature of development). Such common characteristics allowed the identification of six relations between DCs and innovation capacity: innovation capability as a dynamic capability, dynamic capability as an outcome of innovation capabilities, innovation capability as a component of dynamic capability, dynamic capability as a precondition for innovation capability, innovation capability is not a dynamic capability, and innovation capability as a synonym for dynamic capability (Breznik \& Hisric, 2014). However, the findings show some inconsistencies and even 
contradictions, and that a variety of common characteristics that lead to the use of both notions interchangeably should be further developed (Breznik \& Hisric, 2014). The study by Alves et al. (2017) shows that development, management, and transaction capabilities are the dynamic capabilities of innovation and encompass what is needed to ensure "doing the right things", rather than simply "doing the right things" as addressed by Teece (2014). Still, Strønen, Hoholm, Kværner \& Støme (2017) explored and discussed how the DC can be extended, as well as the extent to which the capacity for innovation can be considered dynamic.

It is recognized that the capacity for innovation is built from the literature on DCs as it is possible to observe in several studies on the subject (Lawson \& Samson, 2001; Breznik \& Hisrich; 2014; Alves et al., 2017; Zhou, Zhou, Feng \& Jiang, 2019; Bitencourt, Oliveira, Ladeira, Santos \& Teixeira, 2020), but they are not the same, although both have the same dynamic nature, as they are aimed at ensuring "doing the right things" in the face of the changing nature of the environment or when time is critical (Teece, 2014; Zhou et al., 2019; Bitencourt et al., 2020).

\subsubsection{Firm innovation capacity}

According to Lawson and Samson (2001, p. 380), the firm innovation capacity functions as an integration capacity of a higher order, that is, the ability to shape and manage various resources. Still, Lawson and Samson (2001, p. 384), define firm innovation capacity as the "ability to continuously transform knowledge and ideas into new products, processes and systems for the benefit of the company and its stakeholders". And, Birchall and Tovstiga (2005) state that firm innovation capacity is probably the most important capacity that a company can have. To enhance this, Wang and Ahmed (2007) state that the firm innovation capacity is a critical factor in the evolution and survival of the company in the current changing environment. In Valladares, Vasconcellos and Serio (2014), the definition used for innovation capacity is the same as that of Peng, Schroeder and Shah (2008, p. 735), for whom "firm innovation capacity is the strength or proficiency of a set of practices for the development of new products/processes".

However, the firm innovation capacity is not a single construction, being constituted of distinct elements or determining factors, it is complementary and necessary for the constitution of systematic and sustained forms for the innovation processes that contribute to the generation of results of more effective innovations for improving organizational performance (Lawson \& Samson, 2001; Haldma, Nasi, Grossi, Saunila \& Ukko, 2012; Zawislack, Cherubini, Tello- 
Gamarra, Barbieux \& Reichert, 2012; Saunila, Pekkola \& Ukko, 2014; Valladares et al., 2014; Rajapathirana, \& Hui, 2018; Silva \& Pedron, 2019; Djoumessi et al., 2019; Gloet \& Samson, 2020; Mendoza-Silva, 2021).

One of the definitions that well represents the distinct elements or determinants of firm innovation capacity is that of Valladares, Vasconcellos and Serio (2014), the same used by Peng et al. (2008, p. 735), as it is the result of a systematic review of the literature that culminated in the identification of 16 studies suggesting models or presenting determinants of firm innovation capacity. Additionally, Valladares, Vasconcellos and Serio (2014) surveyed the management practices that support the factors mentioned.

Five models were identified by Valladares, Vasconcellos and Serio (2014): the processbased innovation model, by Chiesa, Coughlan and Voss (1996); the model of innovations in organizations, by Tang (1998); the model of innovation capacity, by Lawson and Samson (2001); the innovation model, by Smith, Busi, Ball \& Meer (2008); and Vasconcelos' model of innovative organization (2008).

The analysis of innovation capacity models existing in the literature conducted by Valladares, Vasconcellos and Serio (2014) allowed us to conclude that there is a strong congruence among its elements, such as the emphasis on organizational culture. However, there are some differences in emphasis and looks. While the Tang (1998) and Vasconcelos (2008) models highlight the systemic view and the relationship with the external environment, Lawson and Samson (2001) draw attention to the balance between exploitation and exploration. Smith et al. (2008) and Vasconcelos (2008) highlight the innovation process. Based on this analysis, a multidimensional structure was synthesized, composed of seven determinants of the capacity for innovation that result in the performance in the innovation of products and processes, as shown in Table I, which are supported by later studies (Rajapathirana, \& Hui, 2018; Silva \& Pedron, 2019; Djoumessi et al., 2019; Gloet \& Samson, 2020; Mendoza-Silva, 2021). 


\section{Table I}

\section{Determinants of innovation capacity}

\begin{tabular}{|c|c|c|}
\hline Factors & Domain & Models \\
\hline $\begin{array}{l}\text { Transformative } \\
\text { leadership }\end{array}$ & $\begin{array}{l}\text { "The one that makes his followers more aware of the } \\
\text { importance and value of work; activates your higher- } \\
\text { order needs, and induces them to transcend their } \\
\text { interests in favor of the organization" }\end{array}$ & $\begin{array}{l}\text { Chiesa, Coughlan e Voss (1996); } \\
\text { Tang (1998); Lawson e Samson } \\
\text { (2001); Smith et al. (2008); } \\
\text { Vasconcelos (2008). }\end{array}$ \\
\hline $\begin{array}{l}\text { Strategic } \\
\text { intention to } \\
\text { innovate }\end{array}$ & $\begin{array}{l}\text { "Degree that the company is willing to take risks to } \\
\text { favor change, technological development and } \\
\text { innovation, and to compete aggressively to obtain a } \\
\text { competitive advantage for its company" }\end{array}$ & $\begin{array}{l}\text { Chiesa, Coughlan e Voss (1996); } \\
\text { Tang (1998); Lawson e Samson } \\
\text { (2001); Smith et al. (2008); } \\
\text { Vasconcelos (2008). }\end{array}$ \\
\hline $\begin{array}{l}\text { Weight } \\
\text { management } \\
\text { for innovation }\end{array}$ & $\begin{array}{l}\text { "Orientation of people management towards } \\
\text { innovation, providing the granting of freedom or } \\
\text { autonomy of action to employees, establishing } \\
\text { challenging goals, allowing them to decide how to } \\
\text { achieve them and favoring self-realization and } \\
\text { commitment to the organization's objectives" }\end{array}$ & $\begin{array}{l}\text { Chiesa, Coughlan e Voss (1996); } \\
\text { Tang (1998); Lawson e Samson } \\
\text { (2001); Smith et al. (2008); } \\
\text { Vasconcelos (2008). }\end{array}$ \\
\hline $\begin{array}{l}\text { Customer and } \\
\text { market } \\
\text { knowledge }\end{array}$ & $\begin{array}{l}\text { "Ability to detect events, needs, expectations, } \\
\text { significant changes and trends from the customer and } \\
\text { the market. Perceiving market changes in front of your } \\
\text { competitors provides the company with a competitive } \\
\text { advantage" }\end{array}$ & $\begin{array}{l}\text { Chiesa, Coughlan e Voss (1996); } \\
\text { Tang (1998); Lawson e Samson } \\
\text { (2001); Smith et al. (2008); } \\
\text { Vasconcelos (2008). }\end{array}$ \\
\hline $\begin{array}{l}\text { Strategic } \\
\text { technology } \\
\text { management }\end{array}$ & $\begin{array}{l}\text { "Management of the technology creation and } \\
\text { development process, aiming at creating value. The } \\
\text { technological management process comprises five } \\
\text { stages: identification, selection, acquisition, } \\
\text { exploitation and protection" }\end{array}$ & $\begin{array}{l}\text { Chiesa, Coughlan e Voss (1996); } \\
\text { Tang (1998); Lawson e Samson } \\
\text { (2001); Smith et al. (2008); } \\
\text { Vasconcelos (2008). }\end{array}$ \\
\hline $\begin{array}{l}\text { Organizational } \\
\text { structure }\end{array}$ & $\begin{array}{l}\text { "Degree in which the structure is characterized by the } \\
\text { granting of autonomy, flexible controls, unimpeded } \\
\text { horizontal communication, valuing knowledge and } \\
\text { experience and informality in personal relationships. } \\
\text { So-called organic structures allow faster response to } \\
\text { changes in the external environment than so-called } \\
\text { mechanistic" }\end{array}$ & $\begin{array}{l}\text { Chiesa, Coughlan e Voss (1996); } \\
\text { Tang (1998); Lawson e Samson } \\
\text { (2001); Smith et al. (2008); } \\
\text { Vasconcelos (2008). }\end{array}$ \\
\hline $\begin{array}{l}\text { Project } \\
\text { management }\end{array}$ & $\begin{array}{l}\text { "Planning, provision of resources, execution and } \\
\text { control of the innovation process. It includes a careful } \\
\text { evaluation of the projects, analysis and planning } \\
\text { aiming, mainly, to gain understanding, commitment } \\
\text { and support, both corporate and of the personnel that } \\
\text { will be involved in the project" }\end{array}$ & $\begin{array}{l}\text { Chiesa, Coughlan e Voss (1996); } \\
\text { Tang (1998); Lawson e Samson } \\
\text { (2001); Smith et al. (2008); } \\
\text { Vasconcelos (2008). }\end{array}$ \\
\hline $\begin{array}{l}\text { Innovation } \\
\text { performance }\end{array}$ & $\begin{array}{l}\text { "Innovative organizations are those that exhibit } \\
\text { consistent innovative behavior over time" }\end{array}$ & $\begin{array}{l}\text { Chiesa, Coughlan e Voss (1996); } \\
\text { Tang (1998); Lawson e Samson } \\
\text { (2001); Smith et al. (2008); } \\
\text { Vasconcelos (2008). }\end{array}$ \\
\hline
\end{tabular}

Source: Elaborated by the author based on the model proposed by Valladares, Vasconcellos and Serio (2014).

The seven determinant factors of the firm innovation capacity that result in the performance of products and processes innovation and make up the multidimensional structure proposed by Valladares, Vasconcellos and Serio (2014) could, according to the authors, be used as a basis for future empirical research or as a guide for improving the firm innovation capacity. 
In this sense, this study, serves as a basis for investigating how the adoption of ISO 56002: 2019 can improve the firm innovation capacity.

\section{Methodological procedures}

The methodology adopted is a comparative analysis of the ISO 56002: 2019 with the literature on firm innovation capacity. Qualitative documentary research (de Oliveira Garcia, Rodrigues, Emmendoerfer, Gava \& Silveira, 2016) and bibliographic research (Soares, Picolli \& Casagrande, 2018) were adopted as research methods in this work.

The methods used in the study included a literature review on the dynamic capabilities and firm innovation capacity and qualitative documentary research.

The literature review was conducted in management research and is a key tool to address the diversity of knowledge in a specific academic area (Tranfield, Denyer, \& Smart, 2003). The review was made in two phases. One to search for published research on dynamic capabilities; the other to deepen the theme and seek research on firm innovation capacity.

The research plan included searching the Ebsco Business Source Premier databases, the CAPES Journal Portal, in addition to Google Scholar.

The following keywords and Boolean operators were used: innovat *, capacit *, capabilit * and then innovat *, dynamic capabilit *. The titles were transferred and archived in the Mendeley Desktop software. The selected articles were classified, coded and archived, according to Crossan and Apaydin (2010) in theoretical articles, literature review or metaanalysis, theoretical-empirical articles, or theory-building and theory-testing.

The articles considered relevant to the description of the company's innovation capacity and its support were recovered until a theoretical saturation point was reached, reached when new references did not add more relevant information or were redundant (Hoffmann \& Farias, 2018).

The documentary research consisted of three phases: the pre-analysis, the organization of the documents and the analysis of the results. In the pre-analysis phase, the objectives of the documentary research were defined, that is, which questions were intended to be answered based on the analysis of the data that in this case involved the understanding of the guidelines and processes of the ISO 56002: 2019 standard. The organization phase sought to facilitate the interpretation of the data, using information from the texts of the guidelines and processes indicated by the ISO 56002: 2019 standard and creating documentary records to record the findings of each material analyzed, which ended up involving the ISO 56000 family for the 
understanding of the concepts provided in the ISO 56002: 2019 standard. Specifically, information from Clauses 4 to 10 of ISO 56002: 2019 was collected. Clauses 0 to 3 were not addressed, as they deal only with introductory aspects of the standard (Clause 0), its scope (Clause 1), normative references (Clause 2) and terms and definitions (3). A classification form to identify general aspects and characteristics of the ISO 56002: 2019 guidelines and processes were prepared, as well as an individual form for each of its Clauses. Thus, with all the sources organized and classified, the analysis of the information was conducted, where the interpretations of the data could contribute to the solution of the research question.

Subsequently, all the information obtained was compiled into a single Microsoft Excel spreadsheet. The analysis was carried out considering the phases of Bardin (2011) for content analysis, a set of techniques of "communication analysis" that uses systematic and objective procedures to describe the content of messages to generate inferences from the content communicated through a text, considering the presence and absence of characteristics in a given fragment of the message. The analyzes followed three phases: the pre-analysis, the exploration of the material and the treatment of the information and its interpretation. In the pre-analysis phase, the general aspects and characteristics of the ISO 56002: 2019 guidelines and processes were collected for each of Clauses 4 to 10. In the material exploration phase, the raw information of each of Clauses 4 to 10 of ISO 56002: 2019 were mirrored in the determinants of innovation capacity proposed by Valladares, Vasconcellos and Serio (2014) described in Chart I. In the information processing and interpretation phase, the information obtained was compiled into a single table in which we sought to express how the adoption of the ISO 56002: 2019 standard can improve the firm innovation capacity.

\section{Discussion}

\subsection{The ISO 56000 family of standards}

The concept of standardized management systems emerged in the context of the standardization movement during the 1980s. ISO published the first version of the ISO 9000 family of standards in 1989 , based on the quality management philosophy developed since the 1950s. systems introduced the process-based view from the Plan-Do-Check-Action (PDCA) cycle (ISO, 2015) which otherwise constitutes an important principle so that all standards can work together based on a structure common high level that allows integration between management systems. This understanding can be observed in Rebelo, Santos and Silva (2015) 
who discuss the possibilities for organizations to establish an integrated management system, incorporating different management systems, including an innovation management system.

At the same time, the British Standards Institute - BSI published the first standard for design management in 1989, developed on a series of standards for design management systems in the following years. BS 7000-1: 2008 Part 1, the guide to innovation management was published in 1999 (BSI, 2008). The standards were developed based on the concept of total design, a process for product design and development, introduced by Stuart Pugh in the 1980s (Hollins, 2000).

Requirements for research and development and innovation $(\mathrm{R} \& \mathrm{D}+\mathrm{I})$ management system were developed by Asociación Española de Normalización y Certificación - AENOR expressed by UNE 166002: 2014, was published in 2002 on an experimental basis, followed by the definitive standard of requirements in 2006 (Mir and Casadesús, 2011; AENOR, 2006) and which today presents itself as UNE 166002: 2014 Gestión de la I + D + i: Requirements of an R \& D \& I Management System. It included the development of the original innovation model by Kline (1985), which had links with the British standard on innovation management (BSI, 2008) and was designed by analogy with the international quality management system standard (ISO, 2015), in addition to being adopted and modified by countries like Portugal, Mexico and Brazil (Mir and Casadesus, 2011; Caetano, 2017).

In Brazil, the Brazilian Association of Technical Standards - ABNT presented the standard ABNT NBR 16501: 2011 - Guidelines for Research, Development and Innovation Management Systems, prepared by the Special Management Study Committee of PD\&I (ABNT / CEE-130), providing guidelines for development and implementation of PD\&I management systems applicable to any organization, independently of size, type and activity.

Spain was also useful in studies of the impact of adhesion by Spanish companies to UNE 166002, of which Mir \& Casadesús, 2011, Mir, Casadesús and Petnji (2016) stand out; Yepes, Pellicer, Alarcon and Correa (2016); and Garechana et al. (2017).

Then, in 2007, initiatives were taken by the European Committee for Standardization CEN, which resulted in the creation of a technical committee in innovation management in 2008, led by AENOR that published a technical specification: Innovation Management - Part 1: Innovation Management System, in 2013, CEN / TS 16555-1: 2013 (CEN, 2013; Caetano, 2017). 
In 2013, ISO created a committee (ISO / TC 279) for innovation management, led by the Association Française de Normalization - AFNOR. As with the European approach, the aim was to develop guidance standards that provide recommendations, not requirements.

The first international standards for innovation management were published in 2019 in what is conventionally called the ISO 56000 family which "aims to provide organizations with guidelines and processes that allow them to get the most out of their innovation projects" (Naden, 2019a) and was developed by the ISO / TC 279 Technical Committee - Innovation Management (ISO / TC 279, 2020), whose secretariat is maintained by AFNOR, an ISO member in France. ISO / TC 279 has worked closely with the Organization for Economic Cooperation and Development - OECD as highlighted by Naden (2020), to share common terminologies and structures for innovation.

As a result, the definitions of "innovation" and "innovation management" are those used in the OECD Oslo Manual: Guidelines for collecting and interpreting innovation data, which is the "main international source of guidelines for collection. and use of data on innovation activities in the industry "(Oslo, 2005). Also, according to Naden (2020) The World Bank Group, the World Intellectual Property Organization - WIPO; and the World Trade Organization - WTO) were also consulted on technical terminology points at various stages of the standard's development. The ISO 56000 family of standards is structured as follows:

a) ISO 56000: 2020 - Innovation management: Fundamentals and vocabulary;

b) ISO 56002: 2019 - Innovation management system - Orientation;

c) ISO 56003: 2019 - Innovation management: Tools and methods for partnership in innovation - Orientation;

d) ISO TR 56004: 2019 - Evaluation of innovation management - Orientation;

e) and subsequent standards (under development) guide tools and methods to support the implementation of the innovation management system

- ISO / DIS 56005: 2021 - Innovation management - Tools and methods for managing an intellectual property - Guidance;

- ISO / CD 56006: 2021 - Innovation management - Strategic intelligence management - Orientation; ISO / AWI 56007: 2022 - Innovation management - ideas management; and 
- ISO / AWI 56008: 2022 - Innovation management - tools and methods for measuring innovation operations - Guidance.

\subsubsection{The ISO 56002: 2019 standard}

According to ISO 56000: 2020 (ISO, 2020a) an innovation management system "[...] is a management system concerning innovation that can be part of an organization's general or integrated management system".

ISO 56002: 2019 “[...] guides the organization to determine its vision, strategy, policy and innovation objectives and establish the support and processes necessary to achieve the intended results" (ISO, 2019), "[.. .] key factor for sustained growth, economic viability, increased well-being and development of society"(ISO, 2019).

The system recommended by ISO 56002: 2019 is based on some principles of innovation management: realization of value, visionary leadership, strategic direction, culture, management of insights, the domain of uncertainty, adaptability, and management by processes. It is represented by a set of interrelated and interactive elements, aiming at the realization and distribution of value translated by Clauses 4 to 10 group related to the PDCA cycle.

Directed by the context of the organization (Clause 4) and its leadership (Clause 5) can be described as follows: Plan: establish the objectives and determine the necessary actions to deal with opportunities and risks - Planning (Clause 6); Do: implement what is planned in terms of support and operations - Support and Operation (Clauses 7 and 8); Verify: monitor and (when applicable) measure the results with the objectives - Performance Evaluation (Clause 9); Act: Take actions to continuously improve the performance of the innovation management system Improvement (Clause 10). As the process progresses, knowledge is acquired and the uncertainty inherent in innovation activities is reduced and the degree of risk-managed.

Additionally, ISO 56002: 2019 applies the framework developed by ISO to improve the alignment between its international standards for management systems, allowing an organization to align or integrate its innovation management system with the guidelines or requirements of other management system standards.

The ISO 56002: 2019 Standard closely follows the established approaches to innovation management, as can be seen in the mirroring conducted between ISO 56002: 2019 against the chapters of Tidd \& Bessant (2021).

However, ISO 56002: 2019 is not free from criticism, such as the implicit adoption of a linear model failing to capture the complexities and contexts for managing innovation, the lack 
of specific tools to support practice such as risk management and uncertainties, which are inherent to many forms of innovation, especially technological and new ventures or any significant variation in the application by sector identified by Tidd (2021).

\subsection{ISO 56002: 2019 and the firm innovation capacity}

From the collection of the general aspects and characteristics of the ISO 56002: 2019 guidelines and processes for each of Clauses 4 to 10 and their relationship with the determinants of the firm innovation capacity proposed by Valladares, Vasconcellos and Serio (2014), Similarities were identified, as each of the factors found a relationship with one or more of these clauses. The information obtained is presented in Table II.

Therefore, Clauses 4 to 10 express a management system in which an organization consciously adheres to a set of organizational practices necessary for the constitution of systematic and sustained forms so that the innovation processes contribute to more effective innovation results and the improvement of the organizational performance (Lawson \& Samson, 2001; Haldma et al., 2012; Zawislack et al., 2012; Saunila et al. 2014; Valladares et al., 2014; Rajapathirana, \& Hui, 2018; Silva \& Pedron, 2019; Djoumessi et al., 2019; Gloet \& Samson, 2020). In this set of practices there are distinct elements or determinants, but complementary factors that constitute firm capacity innovation. When constructed from the literature on DCs (Lawson \& Samson, 2001; Breznik \& Hisrich; 2014; Alves et al., 2017; Zhou et al., 2019; Bitencourt et al., 2020), it is possible to establish a relationship between these determining factors and the guidelines and processes indicated by Standard ISO 56002: 2019 explained in Clauses 4 to 10 as "[...] learned and stable standards of collective activities, through which the company systematically generates and modifies its operational routines in search more effective "(Zollo \& Winter, 2002, p. 340), the company can use it repeatedly and reliably so that it can be considered dynamic (Winter, 2003) or through a more recent approach,“ [...] as a way of responding to dynamic environments by reconfiguring inert and insufficiently flexible ordinary capacities "(Schriber \& Löwstedt, 2020). 


\section{Table II}

Relationships between the determinants of firm innovation capacity and Clauses 4 to 10 of ISO

56002: 2019

\begin{tabular}{|c|c|c|}
\hline Factors & Clauses & Relations \\
\hline $\begin{array}{l}\text { Transformative } \\
\text { leadership }\end{array}$ & $\begin{array}{l}\text { Leadership }-5 \\
\text { Improvement - } 10\end{array}$ & $\begin{array}{l}\text { Demonstrate commitment to the innovation management } \\
\text { system. }\end{array}$ \\
\hline $\begin{array}{l}\text { Strategic } \\
\text { intention } \\
\text { innovate }\end{array}$ & $\begin{array}{l}\text { Planning - 6 } \\
\text { Improvement - } 10\end{array}$ & $\begin{array}{l}\text { Establish the objectives and determine the necessary actions } \\
\text { to deal with opportunities and risks. }\end{array}$ \\
\hline $\begin{array}{l}\text { Weight } \\
\text { management } \\
\text { for innovation }\end{array}$ & $\begin{array}{l}\text { Support - } 7 \\
\text { Operation }-8 \\
\text { Improvement - } 10\end{array}$ & $\begin{array}{l}\text { Implement what is planned in terms of support and } \\
\text { operations. }\end{array}$ \\
\hline $\begin{array}{l}\text { Customer and } \\
\text { market } \\
\text { knowledge }\end{array}$ & Organization context - 4 & Understand the context and scenario for defining strategies. \\
\hline $\begin{array}{l}\text { Strategic } \\
\text { technology } \\
\text { management }\end{array}$ & $\begin{array}{l}\text { Support - } 7 \\
\text { Operation }-8 \\
\text { Improvement - } 10\end{array}$ & $\begin{array}{l}\text { Implement what is planned in terms of support and } \\
\text { operations. }\end{array}$ \\
\hline $\begin{array}{l}\text { Organizational } \\
\text { structure }\end{array}$ & $\begin{array}{l}\text { Support - } 7 \\
\text { Operation }-8 \\
\text { Improvement - } 10\end{array}$ & $\begin{array}{l}\text { Implement what is planned in terms of support and } \\
\text { operations. }\end{array}$ \\
\hline $\begin{array}{l}\text { Project } \\
\text { management }\end{array}$ & $\begin{array}{l}\text { Support - } 7 \\
\text { Operation }-8 \\
\text { Improvement - } 10\end{array}$ & $\begin{array}{l}\text { Implement what is planned in terms of support and } \\
\text { operations. }\end{array}$ \\
\hline $\begin{array}{l}\text { Innovation } \\
\text { performance }\end{array}$ & $\begin{array}{l}\text { Performance Evaluation }-9 \\
\text { Improvement - } 10\end{array}$ & $\begin{array}{l}\text { Monitor and (where applicable) measure results against } \\
\text { objectives. }\end{array}$ \\
\hline
\end{tabular}

Source: Elaborated by the author based on the relationship between the model proposed by Valladares, Vasconcellos and Serio (2014) and Clauses 4 to 10 of ISO 56002: 2019.

In this sense, the findings obtained in Table II suggest that the competitive advantage and innovation results of a company that chooses to adopt the ISO 56002: 2019 standard would originate from the determinants of firm innovation capacity. They would be represented by the guidelines and processes indicated by the ISO 56002: 2019 standard, explained in Clauses 4 to 10 dynamically aligned when composing a set of interrelated and interactive elements, grouped with the PDCA cycle, aiming at the realization and distribution of value. In this way, they would allow the deployment, mobilization and integration of development, management and transaction resources created by the DCs. In this case, they would be focused on ensuring "doing the right things" in the face of the changing nature of the environment or when time is critical (Teece, 2014; Zhou et al., 2019; Bitencourt et al., 2020; Teece, 2014).

In another perspective, it forms a counterpoint to one of Tidd's (2021) criticisms of the failure of ISO 56002: 2019 to capture the complexities and contexts for managing innovation and the lack of specific tools to support practice such as risk management and uncertainties, as the grouping of determining factors concerning the PDCA cycle would allow the continuous 
improvement of the innovation management system to ensure that innovation initiatives and processes are adequately supported, provided and managed, and that opportunities and risks are identified and addressed by the organization. In addition, about specific tools, it is important to understand the breadth of the ISO 56000 family of standards, in which subsequent standards (under development) will guide tools and methods to support the implementation of the innovation management system.

However, the factors investigated do not cover directly Clause 10, subitem 10.3, of ISO 56002: 2019 which deals with continuous improvement, the "recurring activity to improve performance" (ISO, 2020b), and which guides the organization to "[. ..] continuously improve the aptitude, adequacy, effectiveness and efficiency of the innovation management system "(ISO, 2019).

Nevertheless, it is possible to perceive continuous improvement as a transversal item in different clauses of the ISO 56002: 2019 standard as a form of mobilization for action, as it is possible to observe in the following clauses highlighted that of ISO 56002: 2019: Leadership (Clause 5 ) where "senior management should demonstrate leadership and commitment to the innovation management system" (ISO, 2019); Planning (Clause 6) when planning the innovation management system, in addition to other guidelines, "[...] should determine the opportunities and risks that need to be addressed to achieve continuous improvement" (ISO, 2019); Support (Clause 7) in which the guidance to "[...] determine and provide in a timely manner the necessary resources for the establishment, implementation, maintenance and continuous improvement of the innovation management system" is identified (ISO, 2019); and Performance Evaluation (Clause 9) in which "the results of the review by senior management should include considering opportunities for continuous improvement” (ISO, 2019).

Thus, the transversality of continuous improvement in different Clauses of ISO 56002: 2019 may constitute another counterpoint to one of Tidd's (2021) criticisms of the failure of ISO 56002: 2019 to have any significant variation in the application by sector or context, due to this determining factor of the innovation capacity, to allow the company to refine its management system in this direction, singularizing its innovation management system.

\section{Final considerations}

This study aimed to investigate how the capacity for innovation can be improved by adopting the ISO 56002: 2019 standard. The methodology adopted is a comparative analysis of the ISO 56002: 2019 with the literature on firm innovation capacity. The methods employed in 
the study included a literature review on the dynamic capabilities and firm innovation capacity and qualitative documentary research. The data analysis technique used was content analysis. The comparative analysis used general aspects and characteristics of the guidelines and processes for each of Clauses 4 to 10 of ISO 56002: 2019 and their analysis took place against the determinants of the innovation capacity of Valladares, Vasconcellos and Serio (2014). Similarities were identified, as each of the factors found a relationship with one or more of these clauses of ISO 56002: 2019. However, the factors investigated do not include Clause 10, subitem 10.3, of ISO 56002: 2019 which deals with continuous improvement, suggesting the opportunity to introduce a new factor to the structure used for the investigation aimed at continuous improvement of fitness, adequacy, effectiveness and efficiency of the innovation management system.

The findings obtained suggest that the adoption of the ISO 56002: 2019 standard can improve the firm innovation capacity based on its determining, yet complementary factors, necessary for the constitution of systematic and sustained forms for the innovation processes that contribute to the generation of results of more effective innovations to improve organizational performance. These capacities would be represented by the guidelines and processes of ISO 56002: 2019 described in Clauses 4 to 10, grouped with the PDCA cycle, aiming at the realization and distribution of value. The adoption of ISO 56002: 2019 when providing a structure based on the PDCA cycle suggests that the innovation management system can be managed, systematized and replicated by companies. In another perspective, the grouping of the determining factors concerning the PDCA cycle would allow the continuous improvement of the innovation management system to ensure that innovation initiatives and processes are adequately supported, provided and managed, and that opportunities and risks are identified and addressed by the organization promptly for action.

The similarities and differences identified can be used as starting points for researchers interested in studying different models of innovation management, firm innovation capacity and, particularly, the dynamics of continuous improvement of the performance of an innovation management system and its interrelationship. and interaction with other factors, from the theoretical lenses of the DCs or even from other scientific theoretical bases that can be used to support discussions on the topic.

Finally, it is important to note that the findings are specific to the body of literature on the firm innovation capacity built from the literature on DCs. 
Special attention could be given to future studies in two aspects. The first of a more theoretical nature, concerning the conceptual and analytical apparatus that has grown around the DCs and the firm innovation capacity and the potential for contributions arising from their pairing in the fields of strategy and innovation for the resolution of unresolved gaps and tensions, especially the contributions of DCs on the result of innovation. The second, more applied, on how the adoption of the ISO 56002: 2019 standard effects, in addition to the firm innovation capacity, also industries and markets and contributes to economic growth. However, ISO 56002:2019 standard is in its early stages, and a few years of implementation are needed before sufficient data can be collected.

\section{Referências}

AENOR (2006). UNE 166002 Gestión de la I+D+i: Requirements of an R\&D\&I Management System, AENOR.

Albors-Garrigos, J., Igartua, J. I., \& Peiro, A. (2018). Innovation Management Techniques And Tools: Its Impact On Firm Innovation Performance. International Journal of Innovation Management (ijim), 22(06), 1-31.

Alves, A. C., Barbieux, D., Reichert, F. M., Tello-Gamarra, J., \& Zawislak, P. A. (2017). Innovation and dynamic capabilities of the firm: Defining an assessment model. Revista de Administração de Empresas, 57(3), 232-244.

Andrews, K. (1971), The Concept of Corporate Strategy. Irwin: Homewood.

Bardin, L. (2011). Análise de conteúdo 4ªed. Lisboa: Edições, 70, 1977.

Barney, J. (1991). Firm resources and sustained competitive advantage. Journal of management, 17(1), 99-120.

Barney, J. B. (2001a). Resource-based theories of competitive advantage: A ten-year retrospective on the resource-based view. Journal of management, 27(6), 643-650.

Barney, J. B., \& Arikan, A. M. (2001). The resource-based view: Origins and implications. The Blackwell handbook of strategic management, 124-188.

Barney, J., Wright, M., \& Ketchen Jr, D. J. (2001). The resource-based view of the firm: Ten years after 1991. Journal of management, 27(6), 625-641.

Benraouane, S. A., \& Harrington, H. J. (2021). Using the ISO 56002 Innovation Management System: A Practical Guide for Implementation and Building a Culture of Innovation. CRC Press.

Birchall, D., \& Tovstiga, G. (2005). Capabilities for strategic advantage: Leading through technological innovation. Springer. 
Bitencourt, C. C., de Oliveira Santini, F., Ladeira, W. J., Santos, A. C., \& Teixeira, E. K. (2020). The extended dynamic capabilities model: A meta-analysis. European Management Journal, 38(1), 108-120.

Breznik, L., \& Hisrich, R. D. (2014). Dynamic capabilities vs. innovation capability: are they related?. Journal of Small Business and Enterprise Development, 21(3), 368.

BSI (2008). Design management systems - part 1: guide to managing innovation. British Standard BS 7000-1:2008, BSI.

Caetano, I. (2017). Standardization and innovation management. Journal of Innovation Management, 5(2), 8-14.

Casciaro, T., \& Piskorski, M. J. (2005). Power imbalance, mutual dependence, and constraint absorption: A closer look at resource dependence theory. Administrative science quarterly, 50(2), 167-199.

Celukanovs, A., Wattle BJörk, S. (2019). Best Practices for Innovation Management.: A Study on Large Companies in Sweden.

CEN (2013). Innovation management - part 1: innovation management system. CEN/TS $16555-1$.

Chiesa, V., Coughlan, P., \& Voss, C. A. (1996). Development of a technical innovation audit. Journal of Product Innovation Management, 13(2), 105-136.

Crossan, M. M., \& Apaydin, M. (2010). A multi-dimensional framework of organizational innovation: A systematic review of the literature. Journal of management studies, 47(6), 1154-1191.

de Oliveira Garcia, M., Rodrigues, P. E. L., Emmendoerfer, M. L., Gava, R., \& Silveira, S. D. F. R. (2016). Usos da pesquisa documental em estudos sobre Administração Pública no Brasil. Teoria e Prática em Administração (TPA), 6(1), 41-68.

Djoumessi, A., Chen, S. L., \& Cahoon, S. (2019). Deconstructing Lawson And Samson'S Concept Of Innovation Capability: A Critical Assessment And A Refinement. International journal of innovation management, 23(06), 1950053.

Dyer, J. H., \& Singh, H. (1998). The relational view: Cooperative strategy and sources of interorganizational competitive advantage. Academy of management review, 23(4), 660-679.

Egyedi, T. M., \& Ortt, J. R. (2017). Towards a functional classification of standards for innovation research. In Handbook of innovation and standards. Edward Elgar Publishing.

Garechana, G., Río-Belver, R., Bildosola, I., \& Salvador, M. R. (2017). Effects of innovation management system standardization on firms: evidence from text mining annual reports. Scientometrics, 111(3), 1987-1999. 
Gloet, M., \& Samson, D. (2020). Knowledge management and systematic innovation capability. In Disruptive Technology: Concepts, Methodologies, Tools, and Applications (pp. 1198-1218). IGI Global.

Haldma, T., Näsi, S., Grossi, G., Saunila, M., \& Ukko, J. (2012). A conceptual framework for the measurement of innovation capability and its effects. Baltic Journal of Management, 7(4), 355-375

Harrington, H. J. (2019). The Innovation Systems Cycle: Simplifying and Incorporating the Guidelines of the ISO 56002 Standard and Best Practices. Productivity Press.

Helfat, C. E., Finkelstein, S., Mitchell, W., Peteraf, M., Singh, H., Teece, D., \& Winter, S. G. (2009). Dynamic capabilities: Understanding strategic change in organizations. John Wiley \& Sons.

Hoffmann, V. E., \& Farias, J. S. (2018). Saturação teórica em pesquisas qualitativas: relato de uma experiência de aplicação em estudo na área de administração. Revista de Ciências da Administração, 20(52), 40-53.

Hollins, B. (2000). The development of a British standard for innovation management. The Design Journal, 3(2), 27-35.

Hyland, J., \& Karlsson, M. (2021). Towards a management system standard for innovation. Journal of Innovation Management, 9(1), XI-XIX.

International Organization for Standardization - ISO (2013). ISO/TC 279 - Innovation Management. Available in: https://www.iso.org/committee/4587737.html . Accessed on: February 22, 2020.

International Organization for Standardization - ISO (2015). Quality management systems requirements. International Standard, ISO 9001:2015.

International Organization for Standardization - ISO (2019). ISO 56002 - Innovation management - Innovation management system - Guidance. Available in: https://www.iso.org/obp/ui/\#iso:std:iso:56002:ed-1:v1:en. Accessed on: February 22, 2020.

International Organization for Standardization - ISO (2020). ISO 56000:2020 - Innovation management — Fundamentals and vocabulary. Available in: https://www.iso.org/obp/ui/\#iso:std:iso:56000:ed-1:v1:en. Accessed on: February 22, 2020.

International Organization for Standardization - ISO (2020a). ISO/TC 279 - Innovation management. Available in: https://committee.iso.org/home/tc279. Accessed on: February 22, 2020.

International Organization for Standardization - ISO (2020b). ISO 56000 - Innovation management - Fundamentals and vocabulary. Available in: https://www.iso.org/obp/ui/\#iso:std:iso:56000:ed-1:v1:en. Accessed on: February 22, 2020. 
Karlsson, M., \& Magnusson, M. (2019). The systems approach to innovation management. In J. Chen, A. Brem, V. Eric, \& P. K. Wong. The Routledge Companion to Innovation Management. London: Routledge.

Kline, S. J. (1985). Innovation is not a linear process. Research Management, 28(4), 36-45.

Kogut, B., \& Zander, U. (1992). Knowledge of the firm, combinative capabilities, and the replication of technology. Organization Science, 3(3), 383-397.

Lawson, B., \& Samson, D. (2001). Developing innovation capability in organisations: a dynamic capabilities approach. International journal of innovation management, 5(03), 377-400.

Martínez-Costa, M., Jimenez-Jimenez, D., \& del Pilar Castro-del-Rosario, Y. (2019). The performance implications of the UNE 166.000 standardised innovation management system. European Journal of Innovation Management, 22(2), 281-301.

Mavroeidis, V., \& Tarnawska, K. (2017). Toward a new innovation management standard. Incorporation of the knowledge triangle concept and quadruple innovation helix model into innovation management standard. Journal of the Knowledge Economy, 8(2), 653671.

Mendoza-Silva, A. (2021). Innovation capability: A sociometric approach. Social Networks, 64, 72-82.

Merrill, P. (2019). Deep Dive. Quality Progress, 52(5), 56-58.

Mir, M., \& Casadesús, M. (2011). Standardised innovation management systems: A case study of the Spanish Standard UNE 166002: 2006. Innovar, 21(40), 171-188.

Mir, M., Casadesús, M. and Petnji, L. H. (2016). The impact of standardized innovation management systems on innovation capability and business performance: an empirical study. Journal of Engineering Technology Management, 41, 26-44.

Naden, C. (2019a). Shape a new future with innovation management standards. Available in: https://www.iso.org/news/ref2414.html. Accessed on: February 22, 2020.

Naden, C. (2019b). Breaking new ground with better innovation management. Available in: https://www.iso.org/news/ref2368.html. Accessed on: February 22, 2020.

Naden, C. (2020). Shape a new future with innovation management standards. Available in: https://www.iso.org/news/ref2481.html. Accessed on: February 22, 2020.

Nason, R. S., \& Wiklund, J. (2018). An assessment of resource-based theorizing on firm growth and suggestions for the future. Journal of Management, 44(1), 32-60.

Oslo, M. (2005). Guidelines for collecting and interpreting innovation data. Report. Third edition. Oslo: OECD. 
Peng, D. X., Schroeder, R. G., \& Shah, R. (2008). Linking routines to operations capabilities: A new perspective. Journal of operations management, 26(6), 730-748.

Penrose, E.T. (1959), The Theory of Growth of the Firm, Blackwell, Oxford.

Pisano, G. P. (2017). Toward a prescriptive theory of dynamic capabilities: connecting strategic choice, learning, and competition. Industrial and Corporate Change, 26(5), 747-762.

Priem, R. L., \& Butler, J. E. (2001). Is the resource-based "view" a useful perspective for strategic management research? Academy of management review, 26(1), 22-40.

Rajapathirana, R. J., \& Hui, Y. (2018). Relationship between innovation capability, innovation type, and firm performance. Journal of Innovation \& Knowledge, 3(1), 4455 .

Rebelo, M. F., Santos, G. and Silva, R. (2015). Integration of standardized management systems: a dilemma? Systems, 3, 45-59.

Saunila, M., Pekkola, S., \& Ukko, J. (2014). The relationship between innovation capability and performance. International Journal of Productivity and Performance Management, 63(2), 234-249.

Schriber, S., \& Löwstedt, J. (2020). Reconsidering ordinary and dynamic capabilities in strategic change. European Management Journal, 38(3), 377-387.

Schumpeter, J.A. (1934), The Theory of Economic Development. Harvard University Press, Cambridge, MA.

Silva, E. C., \& Pedron, C. D. (2019). Elementos determinantes para a capacidade de inovação das empresas: uma revisão sistemática da literatura| determinants elements for innovation capability of companies: a systematic review of literature. Revista Brasileira de Gestão e Inovação (Brazilian Journal of Management \& Innovation), 7(1), 45-63.

Smith, M. K., Busi, M., Ball, P. D., \& Meer, R. van der (2008). Factors influencing an organisation's ability to manage innovation: a structured literature review and conceptual model. International Journal of Innovation Management. 12(4), 655-676.

Soares, S. V., Picolli, I. R. A., \& Casagrande, J. L. (2018). Pesquisa bibliográfica, pesquisa bibliométrica, artigo de revisão e ensaio teórico em administração e contabilidade. Administração: ensino e pesquisa, 19(2), 1-19.

Strønen, F., Hoholm, T., Kværner, K. J., \& Støme, L. N. (2017). Dynamic capabilities and innovation capabilities: The case of the 'Innovation Clinic'. Journal of Entrepreneurship, Management and Innovation, 13(1), 89-116.

Tang, H. K. (1998). An inventory of organizational innovativeness. Technovation. 19(1), 4151. 
Teece, D. J. (2014). The foundations of enterprise performance: Dynamic and ordinary capabilities in an (economic) theory of firms. Academy of management perspectives, 28(4), 328-352.

Teece, D. J. (2019). A capability theory of the firm: an economics and (strategic) management perspective. New Zealand Economic Papers, 53(1), 1-43.

Teece, D. J., Pisano, G., \& Shuen, A. (1997). Dynamic capabilities and strategic management. Strategic management journal, 18(7), 509-533.

Terwiesch, C., \& Ulrich, K. T. (2009). Innovation tournaments: Creating and selecting exceptional opportunities. Harvard Business Press.

Tidd, J. (2021). A review and critical assessment of the ISO56002 innovation management systems standard: Evidence and limitations. International Journal of Innovation Management (ijim), 24(01), 2150049.

Tidd, J., \& Bessant, J. (2018). Innovation Management Challenges: From Fads To Fundamentals. International Journal of Innovation Management (ijim), 22(05), 1-13.

Tidd, J., \& Bessant, J. R. (2021). Managing Innovation: Integrating technological, market and organizational change. New Jersey: Wiley. Seventh edition.

Tidd, J., Bessant, J. \& Pavitt, K. (1997) Managing Innovation: Integrating Technological, Market and Organisational Change. Great Britain: John Wiley \& Sons Inc.

Valladares, P. S. D. D. A., Vasconcellos, M. A. D., \& Serio, L. C. D. (2014). Capacidade de inovação: revisão sistemática da literatura. Revista de Administração Contemporânea, 18(5), 598-626.

Vasconcelos, M. A. (2008). Modelo de inovação [trabalho não publicado]. Fórum de Inovação, Escola de Administração de Empresas de São Paulo, São Paulo, SP, Brasil.

Wang, C.L. and Ahmed, P.K. (2007). Dynamic capabilities: a review and research agenda. International Journal of Management Reviews, Vol. 9 No. 1, pp. 31-51.

Wernerfelt, B. (1984). A resource-based view of the firm. Strategic management journal, 5(2), 171-180.

Winter, S. G. (2003). Understanding dynamic capabilities. Strategic management journal, 24(10), 991-995.

Yepes, V., Pellicer, E., Alarcon, L. F. and Correa, C. L. (2016). Creative innovation in Spanish construction firms. Journal of Professional Issues in Engineering Education and Practice, 142, 1.

Zahra, S.A., Sapienza, H. and Davidsson, P. (2006) Entrepr.eneurship and dynamic capabilities: a review, model and research agenda. Journal of Management Studies. Vol. 43 No. 4, pp. 917-955. 
Zawislack, P. A., Cherubini Alves, A., Tello-Gamarra, J., Barbieux, D., \& Reichert, F. M. (2012). Innovation capability: From technology development to transaction capability. Journal of technology management \& innovation, 7(2), 14-27.

Zhou, S. S., Zhou, A. J., Feng, J., \& Jiang, S. (2019). Dynamic capabilities and organizational performance: The mediating role of innovation. Journal of Management \& Organization, 25(5), 731-747.

Zollo, M. and Winter, S. (2002). Deliberate learzhouning and the evolution of dynamic capabilities. Organization Science, Vol. 13 No. 3, pp. 339-351. 